\title{
The influence of two different techniques on the particle size and zeta potential of poly(D,L-lactide-co-glycolide) nanoparticles
}

\author{
Influência de duas técnicas diferentes no tamanho e potencial zeta de nanopartículas de \\ poli(D,L-láctico-co-glicólico)
}

\author{
Nuno Martinho, Catarina Rosado and Catarina Pinto Reis \\ CBIOS - Research Center for Health Sciences \& Technologies, Universidade Lusófona \\ Campo Grande 376, 1749-024 Lisboa, Portugal \\ E-mail: catarina.rosado@ulusofona.pt
}

\begin{abstract}
The objective of this study was to analyze different formulation and process parameters and its influence on poly(D,L-lactide-co-glycolide) (PLGA) nanoparticles size and zeta potential prepared by two different methods: spontaneous emulsification solvent diffusion (m-SESD) and solvent displacement (SD). Nanoparticles showed a size range between 200-300 $\mathrm{nm}$ for both methods. The freeze-drying process increased the nanoparticles size for a range of 300-500 $\mathrm{nm}$. The presence of an emulsifier further increased nanoparticles stabilization. On the other hand, the nanoparticles size was dependent upon the type of drug used (ibuprofen or azelaic acid). The production yield obtained was $96.0 \%$ for nanoparticles produced with poloxamer 188 and $94.0 \%$ for nanoparticles produced with sodium laurylsulfate. As a result, it is a very promising formulation in which the $\mathrm{m}$-SESD method was more effective for the analyzed parameters.
\end{abstract}

Keywords: PLGA nanoparticles, m-SESD method, SD method, ibuprofen, azelaic acid

\section{Resumo}

O objectivo deste estudo consistiu na análise de diferentes parâmetros de formulação e processo e a sua influencia no tamanho e potencial zeta de nanopartículas de poli (D,L-láctico-co-glicólico) (PLGA) prepadas por dois métodos diferentes, especificamente, emulsificação espontânea com difusão de solvente (m-SESD) e deslocamento de solvente (SD). As nanopartículas foram produzidas com um tamanho entre um intervalo de 200-300 nm para os dois métodos. O processo de liofilização causou o aumento do tamanho das nanopartículas para 300-500 nm. A presença de agente emulsivo aumentou a estabilidade das nanopartículas. Por outro lado, o tamanho de partículas dependeu do tipo de fárnaco utilizado (ibuprofeno ou ácido azelaico). O rendimento de produção das nanopartículas foi de $96.0 \%$ para as nanopartículas produzidas com poloxamer 188 e de $94.0 \%$ para as partículas produzidas com laurilsulfato de sódio. Este estudo demonstrou esta formulação poderá ser considerada muito promissora sendo que o método mSESD revelou-se mais eficaz para os parâmetros analisados.

Palavras-chave: nanopartículas PLGA, método m-SESD, método SD, ibuprofeno, ácido azelaico 


\section{Introduction}

The material biocompatibility is a fundamental requirement to the design of formulations that fit the physicochemical properties of the drug while modulating its release profiles from the vehicle and having a significant reduction of drug toxicity compared to its free form. Synthetic polymers from the ester family such as PLGA are suitable for drug delivery due to their biodegradability, special release profiles and biocompatibility ${ }^{[1]}$. PLGA is a well known polymer that has been extensively used in medical devices ${ }^{[2,3]}$ as well as in diverse drug delivery applications [4-6]. Several methods have been suggested to produce nanoparticles (NP). The most common difficulties observed are the use of organic solvents, low encapsulation efficiency (EE), higher energy consumption (e.g. ultrasonic generators and homogenizers), non-accepted stabilizers from the point of view of its toxicological profile and presence of residual traces of solvents and salts that are in general incompatible with the drug ${ }^{[7,8]}$. In PLGA nanoparticles production, solvent-diffusion and solvent evaporation methods have been used successfully to produce nanoparticles in an efficient and reproducible manners ${ }^{[9]}$. These methods involve dissolving the polymer in a partially water-soluble solvent. Subsequently, the polymeric solution is diluted with an excess of water containing a stabilizer to promote the diffusion of the solvent ${ }^{[10]}$. Another concern associated with these techniques is the use of organic solvents. Chlorinated solvents, such as dichloromethane (DCM) and chloroform (both ICH class 2), have been widely used in the emulsification process. However, such solvents are associated with environmental concerns. Moreover, the NP size can be strongly influenced by the use of these solvents. On the other hand, spontaneous emulsification solvent diffusion (m-SESD) and solvent displacement (SD) methods commonly use solvents that are considered safe, and easily removed by evaporation. Such methods are simple, inexpensive, versatile for many drugs and easily modified in order to obtain higher $\mathrm{EE}^{[11]}$. The aim of this study is to evaluate the influence of different parameters on the size and zeta potential of nanoparticles. The parameters that were considered relevant were: type of organic phase, different ratios of organic solvents and aqueous phase, type and concentration of stabilizing agents, type of encapsulated drug and finally the influence of the freeze-drying process.

\section{Introdução}

A biocompatibilidade dos materiais é um requisito fundamental para o design de formulações que permitam ajustar-se às propriedades físico-químicas do fármaco e que permitam a modulação da libertação do fármaco veículado e uma redução significativa da sua toxicidade quando este se encontra na forma livre. Os polímeros sintéticos da família ester como, por exemplo, o PLGA, são úteis para a administração dos fármacos devido à sua biodegradabilidade, perfis de libertação e biocompatibilidade ${ }^{[1]}$. O PLGA é um polímero bem conhecido e tem sido extensivamente utilizado em dispositivos médicos ${ }^{[2,3]}$ bem como polímero-base de diversos tipos de veículação de fármacos ${ }^{[4-6]}$. Vários métodos têm sido sugeridos para a produção de nanopartículas (NP). As dificuldades mais comuns observadas durante a produção de NP é a necessidade de recorrer aos solventes orgânicos, baixas eficiências de encapsulação (EE), grande consumo de energia (ex: gerados ultrassónicos e homogenizadores), agentes estabilizantes por vezes não aceitáveis do ponto de vista toxicológico e a presença de solventes residuais bem como sais que são, em regra, imcompatíveis com o fármaco ${ }^{[7,8]}$.

Na produção de partículas de PLGA, os métodos de difusão de solvente e evaporação de solvente têm sido usados com sucesso na produção de nanopartículas ${ }^{[9]}$. Estes métodos envolvem a dissolução do polímero num solvente parcialmente solúvel em água. Posteriormente, a solução do polímero é diluída com um excesso de água contendo um agente estabilizante para promover a difusão de solvente ${ }^{[10]}$. Outra das preocupações associadas a esta técnica diz respeito à utilização de solventes orgânicos. Neste campo, os solventes clorinados, como por exemplo o diclorometano (DCM) e clorofórmio (ambos ICH classe 2), têm sido largamente usados no processo de emulsificação. Contudo, estes solventes levantam algumas considerações preocupantes em termos ambientais. Além disso, o tamanho nas NP obtido pode ser francamente influenciado com a utilização destes solventes. Porém, os métodos m-SESD e SD usam geralmente solventes considerados seguros, os quais são facilmente eliminados por evaporação. Estes métodos são simples, de baixo custo, versáteis para vários fármacos e facilmente modificados de forma a obter maiores $\mathrm{EE}^{[11]}$. O objectivo do presente estudo é avaliar a influência de diferentes parâmetros no tamanho e potencial zeta das nanopartículas. Os parâmetros analisados foram: tipo de fase orgânica, diferentes rácios de solvente orgânicos, tipo e concentração de agente estabilizante, tipo de fármaco e finalmente, a influência da liofilização. 


\section{Materials and Methods}

\section{Materials}

Pluronic ${ }^{\circledR}$ F68 (POLX) was obtained from SIGMA$\mathrm{ALDRICH}^{\mathrm{TM}}$ (USA); Sodium laurylsulfate (SLS) was obtained from Riedel-de Haën ${ }^{\circledR}$ (Germany); Poly(vinyl) alcohol (PVA) 87-89\% hydrolyzed with a MW 1300023000Da was obtained from SIGMA-ALDRICH ${ }^{\mathrm{TM}}$; PURASORB $^{\circledR}$ PDLG 5002 - PLGA (Poly-DLLactide/Glycolide copolymer) Ratio L/G\% 50:50 (MW 45000-75000 Da) was obtained from PURAC; PEG 400 was obtained from AppliChem with MW 380 - 420 $\mathrm{g} / \mathrm{mol}$; Azelaic acid was obtained from SIGMAALDRICH $^{\mathrm{TM}}$ (Germany) Ibuprofen was obtained from SIGMA-ALDRICH ${ }^{\mathrm{TM}}$ (Germany). All other reagents were of reagent grade.

\section{Nanoparticles preparation}

Nanoparticles were prepared by the modified spontaneous emulsification solvent diffusion method (m-SESD) or by solvent displacement (SD). The standard procedure involves an initial emulsion with $100 \mathrm{mg}$ of poly-DL-lactide/glycolide copolymer (PLGA) in acetone in the SD method or in a mixture of acetone/ethanol (with different proportions) in the case o m-SESD method. The mixture was then added at constant stirring of $400 \mathrm{rpm}$ and at room temperature to $10 \mathrm{~mL}$ of a solution with different stabilizers: poloxamer 188 (POLX) 1\% (w/v), sodium lauryl sulphate (SLS) $1 \%(\mathrm{w} / \mathrm{v})$ or poly(vinyl) alcohol (PVA) $4 \%(\mathrm{w} / \mathrm{v})($ the same used in the original m-SESD method) to the previous solution. The resulting solution immediately turned milky due to the formation of a nanoparticles suspension. Subsequently, the organic solvents were thoroughly removed by rotary evaporation. After solvent removal, it was observed a nanoparticles colloidal suspension in water. These particles were named free PLGA NP. Alternatively, the NP containing a drug, ibuprofen (IBU) or azelaic acid (AzA), were prepared following the same techniques except for the addition of the drug in the initial mixture of polymer in acetone or acetone/ethanol.

\section{Extraction method}

After solvent removal, the colloidal suspension was frozen in the freezer at $-20^{\circ} \mathrm{C}$ and freeze-dried for 24-30 hours (FreeZone ${ }^{2.5}$ from LABCONCO).

\section{Particle size and zeta potential measurement}

The particle size and zeta potential were measured in Delsa $^{\mathrm{TM}}$ Nano $\mathrm{C}$ by photon spectroscopy and electrophoretic mobility, respectively. The measurements of size and zeta potential were performed before and after freeze-drying process.

\section{Nanoparticles yield}

The NP production yield was calculated taking into account the composition and weight obtained from $1 \mathrm{~mL}$ of colloidal suspension after removal of the supernatant

\section{Materiais e Métodos}

\section{Materiais}

Pluronic $^{\circledR}$ F68 (POLX) foi adquirido à SIGMAALDRICH $^{\mathrm{TM}}$ (USA); O laurilsulfato de sódio (SLS) foi adquirido à Riedel-de Haën ${ }^{\circledR}$ (Alemanha); O álcool polivínilico (PVA) 87-89\% hidrolizado com peso molecular de 13000-23000 Da foi adquirido à SIGMAALDRICH $^{\mathrm{TM}}$; PURASORB ${ }^{\circledR}$ PDLG 5002 - PLGA (PoliDL-Láctico-co-glicólico) Rácio L/G\% 50:50 (peso molecular 45000-75000 Da) adquirido à PURAC; PEG 400 foi adquirido à AppliChem com peso molecular 380 420; O ácido azelaico foi adquirido à SIGMA$\mathrm{ALDRICH}^{\mathrm{TM}}$ (Alemanha) $\mathrm{O}$ ibuprofeno foi adquirido à SIGMA-ALDRICH ${ }^{\mathrm{TM}}$ (Alemanha). Todos os restantes reagentes foram de pureza analítica.

\section{Preparação das nanopartículas}

As nanopartículas foram preparadas pelo método modificado de emulsificação espontânea com difusão de solvente (m-SESD) or por deslocamento de solvente (SD). No procedimento padrão, preparou-se inicialmente uma emulsão com $100 \mathrm{mg}$ de PLGA em $5 \mathrm{~mL}$ de acetona no caso do método SD ou numa mistura de acetona/etanol (com diferentes proporções) no caso do método m-SESD. Posteriormente e com agitação constante de $400 \mathrm{rpm}$ e à temperatura ambiente foi adicionado $10 \mathrm{~mL}$ de uma solução com diferentes agentes estabilizantes: POLX $1 \%$ $(\mathrm{m} / \mathrm{v})$. SLS $1 \%(\mathrm{~m} / \mathrm{v})$ ou o PVA a $4 \%(\mathrm{~m} / \mathrm{v})($ o mesmo do método original m-SESD) à solução anterior. A solução resultante tornou-se turva devido à formação de uma suspensão de nanopartículas. Em seguida, a mistura orgânica foi submetida ao evaporador rotativo para eliminar o solvente. Após evaporação do solvente, observou-se uma suspensão coloidal de nanopartículas de PLGA em água. Nesta fase, as nanopartículas foram designadas de NP de PLGA vazias. Em alternativa, as NP com fármaco, ibuprofeno (IBU) ou ácido azelaico (AzA), foram preparadas segundo as mesmas técnicas à excepção da adição do fármaco na mistura inicial do polímero em acetona ou acetona/etanol.

\section{Método de extração}

Depois de removido o solvente, esta suspensão foi congelada no congelador a $-20^{\circ} \mathrm{C}$ e liofilizada durante 24 30 horas (FreeZone ${ }^{2.5}$ da LABCONCO).

\section{Medição do tamanho de partícula e potencial zeta}

O tamanho de partícula e potencial zeta foram medidos no Delsa ${ }^{\mathrm{TM}}$ Nano $\mathrm{C}$ através da espectroscopia de fotões e mobilidade electroforética, respectivamente. As medições do tamanho e potencial zeta foram realizadas antes e depois da liofilização.

\section{Rendimento de produção de nanopartículas}

O rendimento de produção das NP foi calculado tendo em conta a composição e o peso obtido de $1 \mathrm{~mL}$ de suspensão coloidal após eliminação do sobrenadante e secagem até peso constante. 
and drying to constant weight.

\section{Statistics}

One-way ANOVA analysis was applied to the mean particle size and zeta potential of different formulations using free NP without stabilizer as a control group. For direct comparison between two groups of data $t$-student test was applied. All tests were performed in GraphPad Prism $5^{\circledR}$ and a statistical significance level of 0.05 was adopted.

\section{Results}

\section{Size of NP: production method}

In the standard m-SESD method a mixture of acetone: ethanol 6:4 was used. However, precipitation was observed and was dependent on the amount of ethanol used (table 1). The ultimate mixture without the occurrence of precipitation was observed with acetone: ethanol 8:2. On the other hand, no polymer precipitation was observed in SD method. At this point an average size of 200-250 nm was obtained for the SD and mSESD 7:3 and 8:2 methods, and approximately $300 \mathrm{~nm}$ for the m-SESD/PVA method. However, comparing the $\mathrm{SD} / \mathrm{POLX}$ with the modified $\mathrm{m}$-SESD method (change of PVA to POLX and $1 \%$ to $4 \%$ ), the m-SESD method was able to produce smaller particles $(183.3 \pm 14.20 v s$. $231.9 \pm 5.39 \mathrm{~nm}, t$-student test, $\mathrm{p}<0.05$ ) (table 2). Also, additional water volume was made after nanoparticles production by $\mathrm{m}$-SESD/POLX method to determine whether or not the solvent diffusion is complete. No differences in size were observed with the extra addition of water $(205.35 \pm 1.34 \mathrm{~nm}$ vs. $183.3 \pm 14.20 \mathrm{~nm}$ from mSESD/POLX). Alternatively, a mixture of acetone: ethanol: DCM (2:1:1) was used. However, in this case extensive aggregation and precipitation was observed after solvent removal. The resulting particles had a size much greater than the ones previously obtained (51.47 \pm $11.46 \mu \mathrm{m})$.

\section{Estatística}

Foi aplicada a análise one-way ANOVA ao tamanho médio de partícula e potencial zeta das diferentes formulações usando como grupo controlo as NP vazias e sem estabilizante. Para comparação directa entre dois grupos de dados foi utilizado o teste de $t$-student. Todas as análises foram realizadas no GraphPad Prism $5^{\circledR}$ com um nível de significancia estatística de 0,05 .

\section{Resultados}

\section{Tamanho da NP: método de produção}

No método padrão m-SESD foi utilizada uma mistura de acetona: etanol de 6:4. Contudo, observou-se precipitação e foi dependente da quantidade de etanol utilizada (ver tabela 1). A melhor mistura sem ocorrência de precipitação foi observada com acetona: etanol de 8:2. No método SD não foi observada precipitação do polímero. Nesta fase foi obtido um tamanho médio de 200-250 nm para o método SD e m-SESD 7:3 e 8:2, e de aproximadamente $300 \mathrm{~nm}$ para o método m-SESD/PVA. Contudo, comparando o método SD/POLX com o modificado do m-SESD (alteração do PVA 4\% para POLX $1 \%$ ), o método modificado m-SESD produziu partículas mais pequenas $(183,3 \pm 14,20$ vs. $231,9 \pm 5,39$ $\mathrm{nm}$, teste $t$-student, $\mathrm{p}<0,05$ ) (ver tabela 2). Adicionou-se ainda uma quantidade de volume extra de água após a produção de nanopartículas pelo método m-SESD/POLX para determinar se a difusão do solvente se dá ou não de forma completa. De acordo com o tamanho de partícula não se verificaram diferenças no tamanho com a adição extra de água $(205,35 \pm 1 ., 34 \mathrm{~nm}$ vs. $183,3 \pm 14,20 \mathrm{~nm}$ do m-SESD/POLX) Alternativamente, foi utilizada uma outra mistura de acetona: etanol: DCM (2:1:1). Porém, observou-se grande agregação e precipitação depois da remoção do solvente. As partículas obtidas apresentavam um tamanho muito superior ao obtido anteriormente $(51.47 \pm 11.46 \mu \mathrm{m})$.

Table 1 - The effect of organic phase composition on PLGA/PVA precipitation and aggregation before and after solvent removal; each $(+)$ represents a qualitative visual scale

Tabela 1 - Efeito da composição da fase orgânica na precipitação e agregação do PLGA/PVA antes e depois da evaporação de solvente; cada $(+)$ representa uma escala visual qualitativa

\begin{tabular}{|lcc|}
\hline \multicolumn{1}{|c|}{ Me dium/meio } & $\begin{array}{c}\text { Precipitate in the dissolution process } \\
\text { Precipitado durante o processo de } \\
\text { dissoluç ão }\end{array}$ & $\begin{array}{c}\text { Large aggr ega tion af ter solvent } \\
\text { evaporation } \\
\text { Extensa agregação depois da } \\
\text { evaporação do solvente }\end{array}$ \\
\hline Ace tone/Acetona & 0 & 0 \\
\hline Ace tone: Ethanol 5:5/Ace tona:etanol 5:5 & +++ & ++ \\
\hline Ace tone: Ethanol 6:4/Ace tona:etanol 6:4 & ++ & + \\
\hline Ace tone: Et hanol 7:3/Ace tona:etanol 7:3 & + & + \\
\hline Ace tone: Ethanol 8:2 /Ace tona:etanol 8:2 & 0 & $0 /+$ \\
\hline $\begin{array}{l}\text { Ace tone: Ethanol:DCM (2:1:1)/ } \\
\text { acetona:e tanol:DCM (2:1:1) }\end{array}$ & 0 & ++ \\
\hline
\end{tabular}


Table 2 - Size, polydispersivity index and zeta potential of different formulations; The m-SESD method used a ratio of acetone: ethanol 8:2; * - A trimodal population was found in one of the batches.

Tabela 2 - Tamanho, indíce de polidespersividade e potencial zeta das diferentes formulações; O método m-SESD usado foi com um rácio de acetona: etanol 8:2; * - Foi encontrada uma população trimodal num dos lotes

\begin{tabular}{|c|c|c|c|c|c|c|}
\hline $\begin{array}{l}\text { Parameter/Parâ } \\
\text { metro }\end{array}$ & $\begin{array}{c}\text { Be fore freeze- } \\
\text { drying /Antes } \\
\text { da liofilização } \\
(\mathrm{n} \mathrm{m})\end{array}$ & P.I./I.P. & $\begin{array}{c}\text { Zeta } \\
\text { potentical/Pote } \\
\text { ncial zeta }(\mathrm{mV})\end{array}$ & $\begin{array}{c}\text { After freeze- } \\
\text { drying/ Depois da } \\
\text { liofilização (n m) }\end{array}$ & P.I./I.P & $\begin{array}{c}\text { Zeta } \\
\text { potencial/Poten } \\
\text { cial zeta }(\mathrm{mV})\end{array}$ \\
\hline $\begin{array}{c}\text { NP free of } \\
\text { stabilizer / NP } \\
\text { sem e st abilizante }\end{array}$ & $346.97 \pm 103.23$ & $0.158 \pm 0.046$ & $-12.04 \pm 4.29$ & $1917,45 \pm 186,61 *$ & $0.711 \pm 0.041$ & -- \\
\hline $\begin{array}{c}\text { SD/POLX } \\
\text { method/método } \\
\text { de SD/POLX }\end{array}$ & $231.90 \pm 5.39$ & $0.037 \pm 0.029$ & $-5.41 \pm 1.89$ & $308.5 \pm 55.24$ & $0.227 \pm 0.036$ & $-4.54 \pm 0.72$ \\
\hline $\begin{array}{c}\text { Original m- } \\
\text { SESD/PVA } \\
\text { method/mét odo } \\
\text { original de m- } \\
\text { SESD/PVA } \\
\end{array}$ & $307.40 \pm 29.53$ & $0.105 \pm 0.072$ & $-0.99 \pm 2.29$ & 422.9 & 0.083 & -- \\
\hline $\begin{array}{l}\text { m-SESD POLX } \\
\text { method/mét odo } \\
\text { m-SESD POLX }\end{array}$ & $194.75 \pm 17.62$ & $0.070 \pm 0.027$ & $-6.75 \pm 3.24$ & $291.15 \pm 21.85$ & $0.224 \pm 0.048$ & $-2.88 \pm 1.44$ \\
\hline $\begin{array}{l}\text { Extra addition of } \\
\text { water/Adição } \\
\text { extra de água }\end{array}$ & $205.35 \pm 1.34$ & $0.091 \pm 0.016$ & $-9.43 \pm 0.049$ & -- & -- & -- \\
\hline $\begin{array}{c}\text { m-SESD } \\
\text { IBU/SLS } \\
\text { method/mét odo } \\
\text { m-SESD } \\
\text { IBU/SLS } \\
\end{array}$ & $234.97 \pm 7.93$ & $0.088 \pm 0.040$ & $-66.01 \pm 1.31$ & $436.85 \pm 3.46$ & $0.287 \pm 0.019$ & $-86.14 \pm 0.28$ \\
\hline $\begin{array}{c}\text { m-SESD } \\
\text { IBU/POLX } \\
\text { method/ mét odo } \\
\text { m-SESD } \\
\text { IBU/POLX }\end{array}$ & $235.53 \pm 8.98$ & $0.054 \pm 0.018$ & $-6.20 \pm 1.31$ & $409.5 \pm 54,80$ & $0.251 \pm 0.036$ & $-4.44 \pm 2.96$ \\
\hline $\begin{array}{c}\mathrm{m}-\mathrm{SESD} \\
\text { IBU/PEG/POLX } \\
\text { method/mét odo } \\
\mathrm{m}-\mathrm{SESD} \\
\text { IBU/PEG/POLX }\end{array}$ & $245.13 \pm 26.33$ & $0.082 \pm 0.077$ & $-19.95 \pm 1.77$ & $585.35 \pm 213.04$ & $0.098 \pm 0.055$ & $-2.19 \pm 5.37$ \\
\hline $\begin{array}{c}\text { m-SESD } \\
\text { AzA/POLX } \\
\text { method/mét odo } \\
\text { m-SESD } \\
\text { AzA/POLX }\end{array}$ & $294.9 \pm 10.49$ & $0.133 \pm 0.017$ & $-4.87 \pm 3.45$ & $379.87 \pm 29.53$ & $0.254 \pm 0.015$ & $-3.94 \pm 2.37$ \\
\hline
\end{tabular}

\section{Size of NP: Type of stabilizer}

Marked differences were observed in the mean particle size for NP prepared with and without stabilizer agent, except for those produced by the original m-SESD method ${ }^{[1]]}$, and those with AzA. On the other hand, no differences were observed between the use of SLS or POLX as stabilizers as well as the addition of PEG in the organic phase.
Tamanho das NP: Tipo de agente estabilizante

Foram observadas diferenças significativas no tamanho médio de partícula preparadas com e sem agente estabilizante, excepto para aquelas produzidas pelo método $\mathrm{m}$-SESD original ${ }^{[11]} \mathrm{e}$ as que utilizaram o AzA. Por outro lado, não foram observadas diferenças entre o uso de POLX ou SLS como estabilizadores assim como da adição de PEG na fase orgânica. 


\section{Size of NP: Type of drug}

The type of drug influenced the particle size. Even though both drugs had statistical differences compared to free PLGA NP, the use of IBU in the formulation produced particles with a size of $235.53 \pm 8.98 \mathrm{~nm}$ which is a similar size found for free PLGA NP $(194.75 \pm 17.62 \mathrm{~nm})$. On the other hand, the use of AzA increased the particle size to $294.9 \pm 10.49$ $\mathrm{nm}(t$-student test, $\mathrm{p}<0.05)$

\section{Size of NP: Drying process}

The freeze-drying process had a $70 \%$ increase in the mean particle size and was more pronounced when IBU was incorporated. On the other hand, no differences were observed between the use of IBU or AzA in dried NP. Also, the freeze-drying process increased the polydispersity index (PI) of NP from $0.090 \pm 0.038$ to $0.203 \pm 0.074$ ( $t$-student test, $\mathrm{p}<0.05$ ).

\section{Zeta potential: Production method}

No differences in zeta potential between the two methods were observed $(-5.41 \pm 1.89 \mathrm{mV}$ and $6.75 \pm 3.24 \mathrm{mV}$ in SD/POLX and $\mathrm{m}-\mathrm{SESD} / \mathrm{POLX}$ method, respectively). On the other hand, the use of PEG in the organic phase increased the stability of the particles with a zeta potential of $-19.95 \pm 1.77 \mathrm{mV}$ compared to $-6.20 \pm 1.31 \mathrm{mV}$ (NP containing the same conditions but without PEG) ( $t$ - student test, $\mathrm{p}$ $<0.05)$.

\section{Zeta potential: Stabilizer type}

For both methods the type of stabilizer changed the zeta potential when comparing free NP and without stabilizer $(-12.04 \pm 4.29 \mathrm{mV})$. Thus, nanoparticles stabilized with POLX $1 \%$ demonstrated a zeta potential of about $-6 \mathrm{mV}$ (for both the SD and $\mathrm{m}$ SESD method), while nanoparticles produced with PVA $4 \%$ showed a zeta potential of $-1 \mathrm{mV}$. On the other hand, nanoparticles produced with SLS 1\% had a zeta potential value of $-66 \mathrm{mV}$.

\section{Zeta potential: Type of drug}

No differences were observed between the use of both drugs in nanoparticles stabilization $(-6.20 \pm 1.31 \mathrm{mV}$ for NP with IBU and $-4.87 \pm 3.45 \mathrm{mV}$ for NP with AzA).

\section{Zeta potential: Drying process}

Although no statistical differences were observed between the formulations, the freeze-drying process produced less stable particles. There was a trend towards a lower stability of nanoparticles after the freeze-drying process except when the SLS $1 \%$ was used as a stabilizer $(t$-student test, $\mathrm{p}<0.05)$ as shown in figure 2 .

\section{Tamanho das NP: Tipo de fármaco}

$\mathrm{O}$ tipo de fármaco influênciou o tamanho da partícullas. Ainda que para ambos se tenha verificado diferenças estatíticas quando comparado com as NP vazias, o uso do IBU na formulação produziu partículas com tamanho de $235,53 \pm 8,98 \mathrm{~nm}$ que é um tamanho semelhante ao observado com as NP vazias $(183,3 \pm 14,20 \mathrm{~nm})$. Por outro lado, o uso de AzA aumentou o tamanho de partícula para $294,9 \pm 10,49 \mathrm{~nm}$ (teste $t$-student, $\mathrm{p}<0,05$ ).

\section{Tamanho das NP: Processo de secagem}

O processo de liofilização aumentou em cerca de $70 \%$ o tamanho médio das partículas sendo mais pronunciado quando o IBU foi incorporado nas partículas. Por outro lado, não foram observadas diferenças de tamanho das partículas secas entre as NP contendo IBU ou AzA. A liofilização aumentou ainda o índice de polidispersividade (IP) das NP de 0,090 00,038 para $0,203 \pm 0,074$ (teste $t$-student, $\mathrm{p}<0,05$ ).

\section{Potencial zeta: Método de produção}

Não se observaram diferenças de potencial zeta entre os dois métodos usados $(-5.41 \pm 1.89 \mathrm{mV}$ e $-6,75 \pm 3,24$ $\mathrm{mV}$ no método SD/POLX e m-SESD/POLX, respectivamente). Por outro lado, o uso de PEG na fase orgânica aumentou a estabilidade das partículas, apresentando um potencial zeta de $-19.95 \pm 1.77 \mathrm{mV}$ em comparação a $-6.20 \pm 1.31 \mathrm{mV}$ (NP contendo as mesmas condições, mas sem PEG) (teste $t$-student, $\mathrm{p}<0.05$ ).

\section{Potential zeta: Tipo de agente estabilizante}

Para ambos os métodos, o tipo de agente estabilizante alterou o potencial zeta comparativamente às nanopartículas livres e sem estabilizante $(-12,04 \pm 4,29$ $\mathrm{mV})$. Assim, as nanopartículas estabilizadas com POLX 1\% demonstratam um potencial zeta de, aproximadamente, $-6 \mathrm{mV}$ (tanto para o método $\mathrm{SD}$ como $\mathrm{m}$-SESD), enquanto que as nanopartículas produzidas com PVA 4\% demonstraram um valor de potencial zeta de $-1 \mathrm{mV}$. Por outro lado, usando SLS $1 \%$ o valor obtido do potencial zeta foi $-66 \mathrm{mV}$.

\section{Potencial zeta: Tipo de fármaco}

Não foram observadas diferenças entre os dois fármacos $(-6,20 \pm 1,31 \mathrm{mV}$ para NP com IBU e $4,87 \pm 3,45 \mathrm{mV}$ para NP com AzA).

\section{Potencial zeta: processo de secagem}

O processo de liofilização produziu partículas menos estáveis mas apesar de não haver diferenças estatísticas entre as formulações. Observou-se uma tendência para uma menor estabilidade das nanopartículas depois do processo de liofilização excepto quando o SLS foi usado como estabilizante (teste $t$-student, $\mathrm{p}<0.05$ ), como demonstra a figura 2 . 


\section{Nanoparticles Yield}

A high production yield was obtained for both the use of POLX $1 \%$ or SLS $1 \%$ as stabilizers with a $96.0 \pm 11.0 \%$ and $94.0 \pm 7.81 \%$ recovery yield, respectively. This results are in accordance to the ones found in literature $(\sim 90 \%)^{[12]}$.

\section{Discussion}

The two production methods used in this study ( $\mathrm{m}$ SESD or SD method) are based on spontaneous phenomena that involve a rapid diffusion of watersoluble solvents to the aqueous phase. In this, PLGA is dissolved in a mixed solution of acetone/ethanol (stage 1) that is further dispersed in an aqueous solution containing a dispersing agent causing an imbalance between the two phases, which spontaneously produces a large interfacial area. An emulsion droplet is formed in the polymer solution that can be explained by the Marangoni effect, in which the desolvated polymer will form a film around. Thus, alcohol diffuses preferentially out of the particulate system (stage 2). Subsequently, the diffusion of acetone reduces the particle size and coacervation occurs by induction of the stabilizing agent diffusion (stage 3). The concentration of PLGA in the particles then increases and due to its low solubility, the droplets solidify and precipitate to form a stable nanoparticle (stage 4). During this process there is the adsorption of the stabilizer to the particle surface which facilitates the stabilization process ${ }^{[1,13-15]}$.

Both methods differ mainly in the composition of the organic phase, in which $\mathrm{m}$-SESD method uses a mixture of acetone: ethanol while SD method only uses acetone. These methods have been effective in NP production and in terms of size the m-SESD was able to produce smaller particles. In this study, we also investigated whether the solvent diffusion is complete or not. To this, extra volume of water was added. No effect on the NP size was observed and this suggests that the diffusion is rather complete. The size differences in the NP obtained by the two methods can be explained by the presence of ethanol. As ethanol diffuses faster than acetone (in higher extension the greater the concentration), this difference in particle size may be due to fast polymer coacervation. On the other hand, it has been observed that ethanol can act as a stabilizer like PVA in NP therefore enhancing the stabilization and reducing particle size ${ }^{[1,12]}$. Nevertheless, it was possible to produce nanoparticles with a size of 200-300 $\mathrm{nm}$ with low PI which is consistent with literature reports with PVA and POLX ${ }^{[7,11,14,16]}$. The average particle size decreases with the use of stabilizers when compared to NP without stabilizer. In fact, aggregation is a

\section{Rendimento de produção}

O rendimento da produção das nanopartículas foi alto quer com POLX $1 \%$ quer com SLS $1 \%$ como agentes estabilizantes tendo sido observada uma recuperação de $96.0 \pm 11.0 \%$ e $94.0 \pm 7.81 \%$, respectivamente. Estes resultados são concordantes com outros estudos na literatura $(\sim 90 \%)$.

\section{Discussão}

Os dois métodos de preparação utilizados neste estudo, m-SESD ou SD, baseiam-se em fenómenos espontâneos que comportam uma difusão rápida de solventes solúveis em água para a fase aquosa. Porém, quando o PLGA é dissolvido numa mistura de acetona/etanol (estágio 1) e esta solução é dispersa numa solução aquosa contendo um agente dispersivo, existe um desiquilíbrio entre as duas fases, a qual produz espontâneamente uma área interfacial larga. A formação de uma gota de emulsão na solução polimérica explica-se através do efeito de Marangoni, no qual o polímero dessolvata para formar um filme à volta. Assim, o álcool difunde-se preferencialmente para fora do sistema particulado (estágio 2). Subsequentemente, a difusão de acetona reduz o tamanho da partícula e ocorre a coacervação do agente estabilizante pela indução desta difusão (estágio 3). A concentração do PLGA dentro da partícula aumenta e devido à pouca solubilidade, as gotículas solidificam e precipitam para formar nanopartículas estáveis (estágio 4). Durante este processo existe a adsorpção do agente estabilizante à superfície da partícula que facilita o processo de estabilização ${ }^{[1,13-15]}$. Os métodos diferem entre si principalmente na composição da fase orgânica sendo que o m-SESD usa uma mistura de acetona/álcool e o método SD apenas acetona. Estes métodos produziram eficazmente NP sendo que em termos de tamanho das NP o méodo m-SESD foi capaz de produzir partículas mais pequenas. Neste estudo foi ainda investigado se a difusão do solvente é ou não é completa. Para isso, foi adicionado um volume extra de água. Nesta fase, não foi observado qualquer efeito no tamanho das NP e tal facto sugere que a difusão terá ocorrido de forma completa. A diferença de tamanho nas NP obtidas pelos dois métodos pode ser explicada pela presença de etanol. Assim, uma vez que o etanol difunde mais rápido que a acetona (em maior extensão quanto maior for a sua concentração), esta diferença no tamanho da partícula pode-se dever a uma mais rápida coacervação do polímero. Por outro lado, também se tem verificado que o etanol pode actuar como o PVA na estabilização das NP e, por isso, ocorrer uma eventual estabilização extra produzindo partículas mais pequenas ${ }^{[11,12]}$. De qualquer modo, foi possível produzir nanopartículas com um tamanho de 200-300 
phenomenon that can occur at various stages of NP production and especially during solvent evaporation ${ }^{[12]}$. The stabilization is due to the formation of a coating on NP surface that prevents aggregation ${ }^{[12]}$.

The presence of a drug influenced the size of NP for both IBU and AzA. IBU was used as model drug since it is slightly soluble in water and has low molecular weight $(206.28 \mathrm{~g} / \mathrm{mol}){ }^{[17]}$. However, with another drug, the results were different and this suggests that the structure of the drug influences the size of the NP. Specifically, the NP size of azelaic acid was about 100 and $60 \mathrm{~nm}$ larger than the free PLGA nanoparticles and ibuprofen, respectively. AzA has similar properties to IBU. In fact, AzA is poorly soluble in water, has a molecular weight of $188.22 \mathrm{~g} / \mathrm{mol}$ and a similar number of oxygen groups to IBU (two carboxylic acid groups for AzA and one for IBU). However, IBU has a benzene ring core while AzA has a long chain. Thus, the internal location of azelaic acid in NP can be different and contributes to increased aggregation.

Zeta potential, is a crucial parameter when applying for a predictive estimate in relation to increased contact time with the drug absorption site. Thus, for transdermal delivery it is known that the skin has a zeta potential of approximately $+23 \mathrm{mV}^{[18]}$ and it would be suitable using negatively charged NP in order to increase the contact time at the absorption site. A similar value was obtained with PLGA. The zeta potential of free NP without stabilizer was $-12 \mathrm{mV}$, which is in agreement with the $-14 \mathrm{mV}$ reported [19]. On the other hand, the presence of stabilizing agents changed the zeta potential. In fact, the repulsion between the NP depends on the electrostatic potential on the surface and therefore the dispersing agents (stabilizers) have a crucial role ${ }^{[20]}$. Several stabilizers have been used in the production of PLGA NP. The most commonly used materials are PVA ${ }^{[17,21,22]}$ and poloxamers ${ }^{[6,7,23,24]}$, while SLS has been seldom used. PVA was the initial choice in this study as a stabilizing agent. The zeta potential was $-0.99 \pm 2.29 \mathrm{mV}$ which hinders the interaction of NP with the site of action. In addition, difficulties in removing it from NP surface have been reported. On the other hand, PVA was not able to effectively stabilize the NP (although the resuspension more easily achieved than with other stabilizers). This zeta potential close to zero was also observed in NP using PEG with POLX as a stabilizer and the same phenomenon was reported in literature ${ }^{[1]}$. The type of stabilizing agent influenced the NP zeta potential in which both PVA and POLX were able to decrease the zeta potential (in absolute value) while SLS increased the value. This can be explained by the adsorption of the stabilizer to the nanoparticles surface. On the other hand, the normal negative zeta potential of PLGA is due to the free carboxyl groups on the particles surface ${ }^{[25]}$ showing some repulsion nm com IP baixos o que está de acordo com o descrito na literatura com o PVA e POLX ${ }^{[7,11,14,16]}$. O tamanho médio da partícula diminui com o uso de estabilizantes quando comparado sem estabilizantes. De facto, a agregação é um fenómeno que pode ocorrer em várias etapas da produção, sendo notavél durante a evaporação do solvente ${ }^{[12]}$. O uso de estabilizantes faz um revestimento na superfície das NP e previne a agregação ${ }^{[12]}$.

A presença de fármaco influênciou o tamanho obtido tanto no caso do ibuprofeno como do ácido azelaico. O ibuprofeno foi utilizado como fármaco modelo uma vez que é pouco solúvel em água e tem baixo peso molecular $(206,28 \mathrm{~g} / \mathrm{mol}){ }^{[17]}$. Porém com outro fármaco, os resultados foram diferentes e este facto sugere que a estrutura do fármaco influencia o tamanho das NP. Concretamente, as NP de ácido azelaico foram aproximadamente 100 e $60 \mathrm{~nm}$ maiores que as nanopartículas vazias e com ibuprofeno, respectivamente. $\mathrm{O}$ ácido azelaico tem propriedades semelhantes ao ibuprofeno. De facto, o ácido azelaico é pouco solúvel em água, tem um peso molecular de $188.22 \mathrm{~g} / \mathrm{mol}$ e apresenta um número semelhante de grupos de oxigénio aos do ibuprofeno (dois grupos carboxilo no ácido azelaico e um no ibuprofeno). Contudo, o ibuprofeno tem um anel benzeno na sua estrutura enquando que o ácido azelaico apresenta uma cadeia longa linear. Assim, a localização interna do ácido azelaico nas NP pode ser diferente e contribuir para o aumento da agregação.

No que se refere ao potencial zeta, esta análise revelase crucial quando se pretende obter uma estimativa predictiva em relação ao aumento do tempo de contacto do fármaco com o local de absorção. Assim, a nível transdérmico sabe-se que a pele tem um potencial zeta de, aproximadamente, $+23 \mathrm{mV}^{[18]}$ e seria de todo conveniente que o potencial das NP fosse negativo de forma a aumentar o tempo de contacto da NP e o local de absorção. Com o PLGA, este valor foi obtido. O potencial zeta para as partículas sem estabilizante foi de $-12 \mathrm{mV}$ o que está de acordo com o $-14 \mathrm{mV}$ reportado anteriormente na literatura ${ }^{[19]}$. Na presença de agentes estabilizantes, o potencial zeta foi alterado. De facto, a repulsão entre as NP depende do potencial electrostático na superfície e os agentes dispersivos (estabilizantes) têm um papel crucial ${ }^{[20]}$.Vários agentes estabilizantes têm sido usados na produção de NP de PLGA e os mais comuns são o PVA ${ }^{[17,21,22]}$ e os poloxamers $[6,7,23,24]$ enquanto que o SLS tem sido raramente usado. O PVA foi a escolha inicial neste estudo como agente estabilizante. O potencial zeta foi de $-0,99 \pm 2,29 \mathrm{mV}$ o que dificulta a interacção da NP com o local de acção. Além disso, têm sido reportadas dificuldades em removê-lo da superfície das NP. Por outro lado, o PVA não foi capaz de estabilizar as NP (apesar de a re-suspensão ter sido a mais fácil em 
ability and stabilization of $\mathrm{NP}^{[26]}$. In fact, it has been observed that pluronic forms a layer that covers the surface of PLGA ${ }^{[26,27]}$. The same effect is observed when PVA is used due to its numerous hydroxyl groups that form a hydrated layer [22] thus reducing the zeta potential to values close to $0 \mathrm{mV}^{[27]}$.

Finally, the freeze-drying process is a common technique for preserving and increasing the stability of $\mathrm{NP}^{[11,14,28,29]}$. During the process, several problems may arise and lead to potential loss of NP integrity. This study showed that freeze-drying increased the mean particle size of the nanoparticles and increased polydispersity index thus the stabilizing agent was not sufficient to prevent aggregation. However, it should be noted that when the stabilizer was not used the freeze-drying process produced microparticles instead. On the other hand, the zeta potential in the nanoparticles decreased with the use of freeze-drying which shows a possible loss of stability of the nanoparticles leading to their aggregation.

\section{Conclusion}

The present study demonstrated that the m-SESD method can be further modified to improve the characteristics of nanoparticles to obtain an optimal size and zeta potential. Both methods were able to produce nanoparticles with size and zeta potential suitable for transdermal administration. These techniques offer a clear advantage as they use low risk organic solvent, do not require high pressure homogenizers and led to large production yields.

\section{Conflict of interests}

The authors declare that there are no financial and personal relationships that could be viewed as presenting a potential conflict of interests. comparação com os outros estabilizantes). Este potencial zeta próximo de zero foi também observado nas NP preparadas com PEG e com o POLX como agente estabilizante e o mesmo fenómeno foi observado na literatura ${ }^{[1]}$. O tipo de agente estabilizante inflenciou o potencial zeta sendo que este diminuiu (em valor absoluto) para ambos o PVA e POLX enquando que o aumento do potencial zeta para o SLS pode ser explicado pela absorção dos agentes estabilizantes na superfície das nanopartículas. Por outro lado, o potencial zeta negativo normal das nanopartículas de PLGA está presente devido aos grupos carboxílicos livres à superfície das partículas ${ }^{[25]}$ e que têm alguma capacidade de repulsão e estabilização das NP ${ }^{[26]}$. De facto, tem sido observado que o pluronic forma uma camada que cobre a superfície do PLGA ${ }^{[26,27]}$. O mesmo efeito acontece quando se usa o PVA no qual os numerosos grupos hidroxilo formam uma camada hidratada ${ }^{[22]}$ reduzindo assim o potencial zeta para valores próximos de $0 \mathrm{mV}^{[27]}$.

Finalmente, a liofilização é uma técnica comum para a conservação e aumento da estabilidade das $\mathrm{NP}^{[11,14,28,29]}$. Durante o processo, vários problemas podem surgir e levar à perda de integridade das NP. Este estudo demonstrou que a liofilização aumentou o tamanho médio nas nanopartículas e aumentou o índice de polidispersividade evidenciando que o agente estabilizante não foi suficiente para prevenir a agregação (note-se que quando não foi usado estabilizante nas NP a liofilização produziu micropartículas). Por outro lado, o potencial zeta nas nanopartículas diminuiu com o uso da liofilização o que evidencia uma possivel perda de estabilidade das nanopartículas que levou à sua agregação.

\section{Conclusão}

O presente estudo demonstrou que o método $\mathrm{m}$-SESD pode ser ainda modificado para melhorar as características das nanopartículas para obtenção de um tamanho ideal bem como potencial zeta. Ambos os métodos de produção produziram nanopartículas com tamanho e potencial zeta adequados para posterior administração transdérmica. Estas técnicas oferecem claras vantagens uma vez que usam solventes orgânicos de baixo risco, não necessitam de homogenizadores de alta pressão e conduziram a grandes rendimentos de produção.

\section{Conflito de Interesses}

Os autores declaram não existir qualquer relação pessoal ou financeira que possa ser entendida como representando um potencial conflito de interesses. 


\section{References / Referências}

1.Ameller, T., et al., Polyester-poly(ethylene glycol) nanoparticles loaded with the pure antiestrogen RU 58668: physicochemical and opsonization properties. Pharm Res, 2003. 20(7): p. 1063-70.

2.Lim, T.Y., C.K. Poh, and W. Wang, Poly (lactic-coglycolic acid) as a controlled release delivery device. J Mater Sci Mater Med, 2009. 20(8): p. 1669-1675.

3.Park, J.K., et al., Guided bone regeneration by poly(lactic-co-glycolic acid) grafted hyaluronic acid bi-layer films for periodontal barrier applications. Acta Biomater, 2009. 5(9): p. 3394-3403.

4.Geldenhuys, W., et al., Brain-targeted delivery of paclitaxel using glutathione-coated nanoparticles for brain cancers. J Drug Target. 19(9): p. 837-845. 5.Vij, N., et al., Development of PEGylated PLGA nanoparticle for controlled and sustained drug delivery in cystic fibrosis. J Nanobiotechnology. 8: p. 22 .

6.Csaba, N., A. Sanchez, and M.J. Alonso, PLGA:poloxamer and PLGA:poloxamine blend nanostructures as carriers for nasal gene delivery. J Control Release, 2006. 113(2): p. 164-172.

7.Song, K.C., et al., The effect of type of organic phase solvents on the particle size of poly $(\mathrm{d}, 1-$ lactide-co-glycolide) nanoparticles. Colloids and Surfaces A: Physicochemical and Engineering Aspects, 2006. 276(1-3): p. 162-167.

8.Zhang, H., et al., Preparation of poly(lactide-coglycolide-co-caprolactone) nanoparticles and their degradation behaviour in aqueous solution. Polymer Degradation and Stability, 2006. 91(9): p. 19291936

9.Rajeev A, J., The manufacturing techniques of various drug loaded biodegradable poly(lactide-coglycolide) (PLGA) devices. Biomaterials, 2000. 21(23): p. 2475-2490.

10.Pinto Reis, C., et al., Nanoencapsulation I. Methods for preparation of drug-loaded polymeric nanoparticles. Nanomedicine : nanotechnology, biology, and medicine, 2006.2(1): p. 8-21.

11. Murakami, H., et al., Preparation of poly(DLlactide-co-glycolide) nanoparticles by modified spontaneous emulsification solvent diffusion method. Int J Pharm, 1999. 187(2): p. 143-152.

12.Cheng, F.-Y., et al., Stabilizer-free poly(lactide- co-glycolide) nanoparticles for multimodal biomedical probes. Biomaterials, 2008. 29(13): p. 2104-2112.

13.Kawashima, Y., et al., Properties of a peptide containing DL-lactide/glycolide copolymer nanospheres prepared by novel emulsion solven diffusion methods. Eur J Pharm Biopharm, 1998. 45(1): p. 41-48

14.Murakami, H., et al., Further application of a modified spontaneous emulsification solven diffusion method to various types of PLGA and PLA polymers for preparation of nanoparticles. Powder Technology, 2000. 107(1-2): p. 137-143.

15. Quintanar-Guerrero, D., et al., Preparation and characterization of nanocapsules from preformed polymers by a new process based on emulsificationdiffusion technique. Pharm Res, 1998. 15(7): p. 1056-1062.

16.Stevanovic, M.M., B. Jordovic, and D.P. Uskokovic, Preparation and characterization of poly(D,L-lactide-co-glycolide) nanoparticles containing ascorbic acid. J Biomed Biotechnol, 2007.2007(7):p. 84965

17.Hasan, A.S., et al., Effect of the microencapsulation of nanoparticles on the reduction of burst release. Int J Pharm, 2007. 344(1 2): p. 53-61.

18.Morykwas, M.J., J.W. Thornton, and R.H. Bartlett, Zeta potential of synthetic and biological skin substitutes: effects on initial adherence. Plast Reconstr Surg, 1987.79(5): p. 732-739.

19.Cheng, F.Y., et al., Stabilizer-free poly(lactide-coglycolide) nanoparticles for multimodal biomedica probes. Biomaterials, 2008. 29(13): p. 2104-12.

20.Bouchemal, K., et al., Nano-emulsion formulation using spontaneous emulsification: solvent, oil and surfactant optimisation. Int J Pharm, 2004. 280(1-2): p. 241-251.

21.Rolland, A., et al., Site-specific drug delivery to pilosebaceous structures using polymeric microspheres. Pharm Res, 1993. 10(12): p. 17381744.

22.Song, $X$, et al., PLGA nanoparticles simultaneously loaded with vincristine sulfate and verapamil hydrochloride: systematic study of particle size and drug entrapment efficiency. Int J Pharm, 2008. 350(1-2): p. 320-9.

23.Parajo, Y., et al., PLGA:poloxamer blend microand nanoparticles as controlled release systems for synthetic proangiogenic factors. Eur J Pharm Sci. 41(5): p. 644-649.

24.Fonseca, C., S. Simoes, and R. Gaspar, Paclitaxel-loaded PLGA nanoparticles: preparation, physicochemical characterization and in vitro antitumoral activity. J Control Release, 2002. 83(2): p. 273-286.

25.Yang, R., et al., Enhanced electrostatic interaction between chitosan-modified PLGA nanoparticle and tumor. International Journal of Pharmaceutics, 2009. 371(1-2): p. 142-147.

26.Santander-Ortega, M.J., et al., Colloidal stability of pluronic F68-coated PLGA nanoparticles: a variety of stabilisation mechanisms. J Colloid Interface Sci, 2006.302(2): p. 522-529.

27.Sahoo, S.K., et al., Residual polyvinyl alcohol associated with poly (D,L-lactide-co-glycolide) nanoparticles affects their physical properties and cellular uptake. J Control Release, 2002. 82(1): p. 105-114.

28.Choi, S.H. and T.G. Park, G-CSF loaded biodegradable PLGA nanoparticles prepared by a single oil-in-water emulsion method. Int J Pharm, 2006.311(1-2): p. 223-228.

29.Katas, H., E. Cevher, and H.O. Alpar, Preparation of polyethyleneimine incorporated poly(D,L-lactideco-glycolide) nanoparticles by spontaneous emulsion diffusion method for small interfering RNA delivery. Int J Pharm, 2009. 369(1-2): p.144-154 